that we could make a machine to utilise some of the energy in the ether ; but does any one profess to know so much of that remarkable thing as to be quite certain that this is impossible? Any way, there is no doubt that to a considerable degree of accuracy inertia is a constant property of a body, and equal inertias may consequently be very reasonably considered as equality of such a very important property of two bodies, that scientific people are justified in their shortly describing the bodies as equal, which is what they usually do, and is all that they can really mean when they speak of equal quantities of iron and gold. Why, then, trouble unfortunate students with the idea that there is some huggermugger metaphysical "quantity of matter" called " mass," of which they are supposed to have a clear and definite conception distinct from this equality of inertia? Why not call it inertia when it is inertia that is meant, and drop out of use that word "mass," round which such a tissue of indistinct and obscure ideas have grown, that it is almost hopeless to separate it from them.

I hope some word more euphonious than "slug" will be found for the unit of inertia on the engineer's system. I would suggest " ert" as a term that would easily recall the quantity inertia.

Trinity College, Dublin, February Io.

\section{The Flight of Gulls in the Wake of Steamers.}

MANY persons have remarked the extraordinary power displayed by gulls of keeping pace with a steamer without any motion of their wings. A few days ago, I had a good opportunity of observing this during a voyage from Alexandria to Marseilles.

When the wind was blowing at right angles to the course of the vessel, having first gained some slight elevation, the gulls would glide downwards with expanded wings, making, during the descent, rapid progress in the same direction as the steamer. When quite near the water they would suddenly turn and face the wind, at the same time giving their bodies an upward incline, and the wind would lift them to their former elevation, after which the process would begin again. A wind blowing horizontally has the power of lifting, only because each stratum, so to speak, of air moves more rapidly than the stratum immediately below it. Consequently, as the bird rises, it has the inertia due to the fact that it has just emerged from the slower current below. Thus it may be compared to a kite, the inertia taking the place of the string. When gulls progress in this way, at right angles to the wind, the vessel does not in any way assist them, and, occasionally, when they are not following a steamer, they may be seen employing the same method.

With a head-wind they advance with even greater ease. To understand how this is possible, some investigation of the aircurrents behind the ship's stern is necessary. If small pieces of paper are thrown overboard when a strong head-wind is blowing, they are seized by a tremendous down-draught, but, some few yards astern, they suddenly dart up again. In fact, as the vessel moves onward, the air rushes down to fill the vacuum, then rebounds off the surface of the sea, and forms an up-current. Placing himself in this up-current, the gull is lifted as if he were no heavier than a scrap of paper, then he glides downward and onward. But as the vessel moves on, the up-current advances, or, strictly speaking, the point at which the up-current is formed. At the end of his descent the gull finds himself in this, is again lifted, and the process is repeated.

When the wind was not a due head-wind, but struck the vessel at a slight angle, now and then a gull would be seen apparently hovering motionless over the stern, of course really gliding onward with the vessel. Though I cannot speak with confidence of the explanation of this, the most wonderful of the methods employed, I wish to put forward what seems the probable explanation. The wind striking against the side of the vessel is deflected upwards, and it is this up-current which buoys up the gull as he floats over the stern. Though it may appear that his progress is perfectly uniform, I think it will be found that in advancing he descends slightly, that he often loses ground for a time, and that while losing ground he ascends. Thus the method in this case is really the same as in that last described. Unfortunately, I was not able to prove the existence of this up-current about 20 feet above the stern of the vessel. But there is good evidence of it in the fact that the gull remains suspended there without a motion of his wings. Without an No. I 426 , vOL. 55$]$ up-current this would be an impossibility. It is to be hoped that good observers will give their attention to these very interesting phenomena.

Haileybury, February 8 F. W. Headley.

\section{Two Unfelt Earthquakes}

ON February 7, commencing at about 8 a.m., G.M.T., an unusually large, but, at the same time, unfelt earthquake was recorded in the Isle of Wight. The preliminary tremors, which include three well-defined maxima, extended over twenty-six minutes. After these came two periods of heavy movement, each extending over fifteen or twenty minutes. The duration of the whole disturbance was about one and one-half hours. It was Japanese in character, and because it was recorded in Tochia by Dr. G. Grablovitz, and at the same time was so marked in ampli. tude and duration, it is not unlikely that it disturbed the entire surface of the globe.

On the I 3 th there was a comparatively small disturbance, with preliminary tremors of three or four minutes, at about to a.m. I should be pleased to learn whether these earthquakes were recorded by bifilar pendulums in Edinburgh or Eirmingham, or at any of our magnetic observatories.

Shide, Newport, I.W., February 18. JOHN MiLNE.

\section{FOUNDATIONS OF CORAL ATOLLS.}

THE most regrettable failure of the boring lately attempted in the coral atoll of Funafuti has left us as wise as we were as to the actual structure of these formations; but the surveys carried on by H.M.S. Penguin, both at $F$ unafuti and in the regions round about, have afforded information which, I think, is of value in elucidating some of the problems to be solved, and which has certainly strengthened some of my own views on the subject.

Funafuti, it may be mentioned, was selected for investigation as being one of a great Pacific group of atolls, which must have a common great cause for the formation of their necessary foundations, and for their development; groups which had a great share in causing $\mathrm{Mr}$. Darwin to conclude, from the lack of other explanation of banks in large numbers at a proper depth for the growth of an atoll, that subsidence on a large scale was the predominant agent in their production ("Coral Reefs," 2nd ed., pp. I I 8 , I19; 3rd ed., pp. I20, 121.)

Firstly, the sounding carried on by the Penguin round Funafuti and between separate islands of the Ellice Group, show incontestably that each atoll is situated on a separate mound, rising from a more or less even bottom of great depth below the surface. This proves that there has never been anything of the nature of a range of continental land which has gradually sunk beneath the waves. Each atoll, if it has sunk, has subsided independently, with its own isolated volcanic peak.

Secondly, the Penguin, while searching the seas some 250 miles to the south-westward of the Ellice Islands for several reported dangers to navigation, explored four banks, all of submerged atoll form, lying near one another.

The remarkable thing about these banks is the absolute uniformity of the depth of water over their areas, ins:de the low rim of growing coral which encircles their edges in various degree. This depth is 24 to 26 fathoms. The banks are large : one is 22 miles by 10 ; another is 18 miles by 9 ; the third is 8 by 7 ; and the fourth 4 by 3. The plan of one of them is given on the next page as an example.

Another bank, investigated a few years ago by H.M.S Waterwitch, and lying 400 miles to the eastward, presents similar characteristics, and the same depth over its central area. All these banks are situated in a region exposed to the same conditions of wind and sea.

What causes this remarkable similarity of depth and this extraordinarily even surface over these large banks? Is 
Cables 10

\section{ALEXA BANK}

Surveyed by

Capt. A.M. Field \& the Officers

H.M.S. Penguin.

Oct: 1896.

Soundings in fathoms.

West Point $\left\{\begin{array}{l}\text { I at: } 111^{\circ} \cdot 36: 20 " \mathrm{~S} . \\ \text { Long: } 175,8.30 \mathrm{E}\end{array}\right.$
Scale of Nautical Miles



588

723





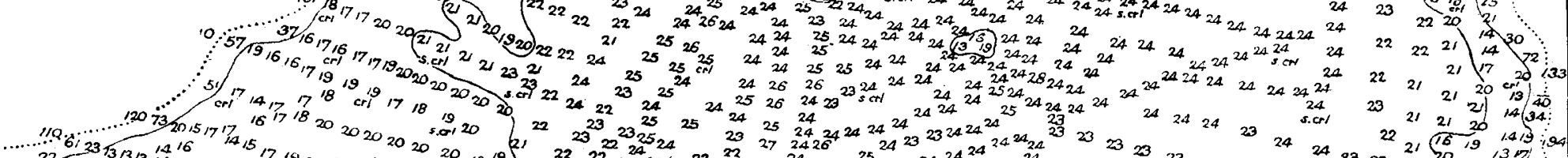

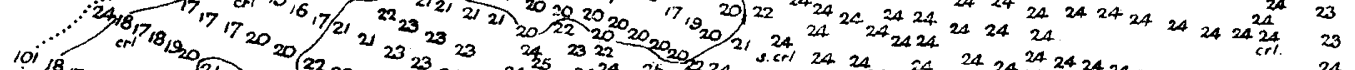





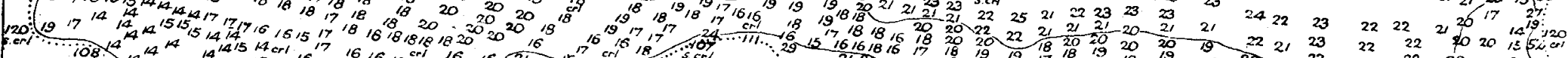

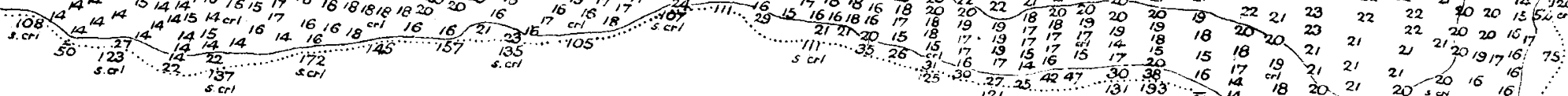





$$
\begin{aligned}
& \left(\begin{array}{llllll}
17 & 19 & 18 & 18 & 20 & 17 \\
15 & 17 & 18 & 17 & 16 & 15
\end{array}\right. \\
& 45 \quad 25 \quad 17 \quad 17 \quad 15 \quad 19 \%
\end{aligned}
$$

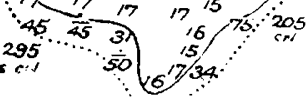

$$
\begin{aligned}
& \text { जि }
\end{aligned}
$$


it uniform subsidence of mounds, of identical height, over a great area? Is it building up of mounds to an identical distance below the surface? I cannot think that either can account for the conditions. I would venture to suggest the cutting down of volcanic islands by the action of the sea, and that this operation has a far greater share in furnishing coral foundations than has generally been admitted.

The operation has not been overlooked. Mr. J. Murray says: "Volcanic mountains ... like Graham Island, might be wholly swept away, and only a bank with a few fathoms of water over it be left on the spot. In this way numerous foundations may have been prepared for . . . even atolls" (Proc. Roy. Soc. Edin., vol. x. p. 507). Sir A. Geikie, in referring to Murray's views, says, "those portions of volcanic mountains that rise above the sea-level are worn down by the atmosphere and waves, and unless otherwise preserved, must eventually be reduced to the lower limit of effective waveaction, which is probably nearly coincident with the lower limits of reef builders."

I can find, however, but little further reference to it, and prominence has not been given to it as a principal cause, as has been given to, on the one hand, subsidence, or, on the other, the building up of mounds by organisms other than corals.

Darwin specially rejects it. He says ("Coral Reefs," 2nd ed., p. I24): "It will probably occur to those who have read Ehrenberg's account of the reefs of the Red Sea, that many points in these great areas may have been elevated, but that, as soon as raised, the protuberant parts were cut off by the destroying action of the waves: a moment's reflection, however, on the basin-like form of the atolls, will show that this is impossible ; for the upheaval and subsequent abrasion of an island would leave a flat disc, which might become coated with coral, but not a deeply concave surface; moreover, we should expect to see, at least in some parts, the rock of the foundation brought to the surface."

Let us now consider the general condition of the material piled up by a submarine volcano.

I find that David Forbes (Geol. Mag., 187o, p. 323) is of opinion that erupted lava meeting water will assume the form of scoriæ, tufa, ash, and similar loose and subdivided matter, and I believe that many other geologists will agree. Instances of recently-formed volcanic islands add testimony to the correctness of this view. Graham Island, near Sicily, was all ash, and quickly disappeared. The new island in the basin of Santorin, formed in 1866 , is all ash, as I know from personal investigation. Falcon Island, near the Tonga Group, which appeared in 1885 , is all ash, and is now reduced to a small proportion of its original dimensions. Sabrina Island, on the flank of St. Miguel in the Azores, was formed in I8II, all of loose material, and was washed away to a depth of $\mathrm{I} 5$ fathoms in a short time. What water is now over it is not known.

No doubt when an ash mound has assumed sufficient dimensions to resist the percolation of water, the lava will be poured out in a mass and solidify, and form a mountainous island of the familiar oceanic type; but it appears to me that all the evidence goes to show that an enormous proportion of the material ejected by a submarine volcano will be loose, until a great height above the sea is attained.

If this be granted, here is an easy material for the sea to work upon. The next point is, to what depth does the action of the sea attain?

To those unacquainted with the ocean it may seem incredible that it can be in motion sufficiently violent to, at depths of 50 and 60 fathoms, move material; but I think that there is good evidence of it.

An isolated rock exposed to the full strength of the sea from one of the great oceans will cause a heavy breaker on the surface, when it is submerged as much as Io fathoms. Let us think for a moment what this means, and what the horizontal velocity of the water at the depth of the rock must be to cause such a disturbance at the surface.

All who have studied the submarine contours of the land exposed to the great oceans, will know the remark. able fact that there is in the great majority of cases a sudden steeper fall at the depth of from 80 to Ioofathoms. This can only be explained on the supposition that the material eroded from the coasts can be moved and distributed to that depth.

The depth at which matter can be moved will, of course, vary with its size and tenacity. It is sufficient for my purpose if it is only fine mud and sand which is acted upon at such a depth as 80 fathoms, although submarine cables have been taken up which show evidence of having been moved and chafed at even greater depths.

Cables have been recovered which show that breakage has occurred from their being moved in 260 fathoms, and, by the kindness of Mr. F. Lucas, I have in my own possession a steel wire forming part of the outer covering of the Brazilian cable, picked up from I 40 fathoms, which is worn down on one side as with a file. The records of the Cable Companies can furnish numerous similar instances.

While there are, as might be expected, banks in the oceans of every conceivable depth, there are a very large number with a depth over them, which is to my mind conformable to the depth to which wave action extends.

I may instance the great bank on which the Seychelles Islands stand. This is roughly 16,000 square miles in area, and has a general depth over it of 30 fathoms, though it is not so absolutely flat as banks less gigantic.

In the course of recent hydrographical operations it has been gradually borne in upon my mind that banks at great depth can reveal themselves upon the surface. Numerous instances have occurred where, on search being made for the cause of reported "breakers," deep banks, some lying as far below the surface as 800 fathoms, have been found on the spot, but nothing shoaler could be detected. "Rips" have, however, been seen in the course of the search, and steered for in the expectation that shallow water existed, but to no purpose. In such cases it seems probable that it is the tide (which extends to the bottom of the sea) meeting the obstacle of the bank, which is accelerated to such an extent that it affects the surface.

I have, therefore, no difficulty in believing that volcanic ash can be moved at depths of 30 fathoms, or more, when exposed to the action of waves in an otherwise deep sea, over which strong winds are continually blowing.

The effect will be to cut down an island more or less rapidly, according to its constitution, to a very considerable depth below the surface; the final result being a perfectly flat bank.

Mr. Darwin, as above quoted, speaks of a flat bank as unrepresentative of the floor of an atoll ; but I think that this was a consequence of the comparatively small amount of facts at his disposal.

I have no hesitation in saying that a flat floor is an invariable characteristic of a large atoll, and I cannot find his "deeply concave surface" in any large atoll. On the contrary, a flat surface is found in all of these, whether the rim be above or below the surface.

It is true that towards the sides of a lagoon the depth gradually lessens; the encircling rim is not so steep as it is on the outside, but I think this is only what would be expected from the less vigorous growth of coral on the inner side of the rim as it rises, and from the gradual dissemination of débris from the rim thrown over by the waves.

I fail to see how subsidence of a solid peak, or the elevation of a submerged peak by the growth of

No. I 426 , VOL. 55$]$ 
organisms, will explain a flat floor, without bringing in the action of the sea at considerable depths. In a subsiding peak with a barrier reef, there cannot be sufficient wave-action to level a large lagoon. In a bank rising by growth, why should it become level over its whole surface?

A further point remains. Can coral settling on a bank, 30 fathoms or so beneath the surface, form an atoll? Mr. Darwin limits this possibility to "some fathoms submerged," and considers that " $\mathrm{it}$ is an assumption without any evidence that at a depth at which the waves do not break, the coral grows more vigorously on the edges of a bank than on its central part."

$I$ think that the experience of the years since $\mathrm{Mr}$. Darwin wrote that, has given us evidence that this is not an unwarrantable assumption.

The instances of shallow narrow rims, or of isolated patches of coral on the edges of such banks, are now innumerable.

It is so well recognised that the edge of such a bank is the place to expect shoal patches, that in carrying out hydrographic surveys in coral regions it is the edge that is most minutely searched. On such edges are found evidence of coral colonies in every stage; complete ridges, broken ridges, and mere patches here and there.

Always, where means have permitted, is evidence brought up that such colonies are alive. There may be dead rims, but they are the exception.

The fact of a current, whether tidal, or otherwise induced, being accelerated on meeting a submarine bank is, I think, sufficient to account for this. The water pours over the edge of the bank, and brings abundance of food to those corals which settle on it, to the disadvantage of those settling further in.

The phenomena of coral patches and ridges on the edge of these submerged banks is so frequent, that I know not how they can be otherwise explained. The great Seychelles Bank is lined all round its edge, so far as examined, with such coral ridges and patches. The small islands, in this case of primary rock, in the centre of this bank are lined with fringing reefs; and if the whole bank, I 50 miles in length, has uniformly sunk, they must have sunk too, and the fringing reefs would be beneath the surface.

Given these edgings of vigorous living coral on submerged banks, of which I consider we have indisputable proof, they will certainly grow to the surface and form the complete atoll. In the earlier stages calcareous organisms of all kinds will settle all over the bank, giving it a coating more or less thick according to circumstances.

The only other point that need be mentioned is the steep slope that characterises some atolls. As to this, I believe that masses with irregular projections like broken coral, falling down in water, will entangle themselves, and lie at a steepness of slope unknown in similar falls on mountain sides, and though the aid of subsidence may be needed for the almost vertical walls which occasionally occur, that the slopes of most atolls can be explained without it.

There seems no necessity to call in the aid of Murray's theory of deepening and widening of the lagoon by solution, but I am not contending that it may not so act. What I am concerned to show is that without it, and without subsidence, deep and large atolls may be formed, and that we have abundant evidence of atolls so forming.

I am not arguing that there has been no subsidence; indeed, I think that a volcanic cone, from the nature of its loose material, will frequently subside, and that some of the deeper lagoons may owe their depths of 50 fathoms or so to such a movement, quite apart from subsidence of large areas which we know occurs. Nor do I say that volcanic mounds that have failed to reach the surface, may not be built up to a sufficient height for corals to flourish; nor that all foundations and atolls

$$
\text { NO, I } 426 \text {. VOL. } 55]
$$

have been formed in the same way; but I put forward the hypothesis that the cutting down of volcanic islands by wave-action and currents, has had a greater share in providing suitable bases for coral atolls than any other process of nature.

I may further suggest, in defence of my views, that it tends to explain why, over vast groups of atolls, no central summit is left.

W. J. L. WHARTON.

\section{FRIDTJOF NANSEN'S "FARTHEST NORTH." "}

WHEN Gerrit de Veer published his "True ano perfect description" of Barents' voyages for the discovery of a North-east passage, "so strange and woonderfull that the like hath never been heard of before," he justified himself for doing so by several reasons :-

"And also to stoppe their mouthes, that report and say, that our proceeding therein was wholly unprofitable and fruitelesse; which peradventure in time to come, may turn unto our great profite and commoditie. For he which proceedeth and continueth in a thing that seemeth to be impossible, is not to be discommended; but hee, that in regarde that the thing seemeth to be impossible, doth not proceed therein, but by his faint-heartedness and sloath, wholly leaveth it off."

This might not inappropriately be taken as an apology for Nansen's popular account of his great Arctic journey, which in many ways finds its nearest prototype in the classic adventures of the Dutch explorers three hundred years ago, when the lifting of a ship on the ice without being nipped was first observed, and the nature and effects of ice-pressures were first clearly described. For an example of a Norse Arctic explorer visiting England and receiving a Royal welcome; we must go back a thousand years to the time when King Alfred entertained Othar, and gave in a gloss on his Orosius the first record of Arctic discovery ever written in the language of the English. But between the visits of Othar and Nansen the progress of Arctic discovery has been due mainly to our countrymen, who have purchased with their lives much of the experience on which the safe and successful voyage of the Fram was planned.

These large and handsome volumes, giving the full narrative of the voyage, have been very rapidly prepared, too rapidly for the careful reader, who has been sacrificed to allow the eager public to revel in a story of adventure. More leisurely preparation might have left the book no less readable, and made it much more valuable; by including at least a few preliminary reports on the results of the voyage which must necessarily be of "great profite and commoditie" in many branches of knowledge. The revision of the text might have been more complete, the cumbrous title-page might have assumed a pleasing form, there might have been a prefatory note acknowledging the author's debt to the translators, whose work certainly deserves recognition, and the maps might have been of a less provisional character. Scientific readers will, however, be content to await the full discussions by specialists, which are doubtless in preparation, and meantime they cannot dip into the narrative of the most successful of all Arctic voyages without becoming absorbed by its peculiar fascination. The glamour of the Arctic regions has been felt by almost every explorer, and not a few have succeeded in passing it on to the readers of their books, but none so perfectly as Dr. Nansen. Too often the tale

1 Fridtjof Nansen's " Farthest North," being the Record of a Voyage of Exploration of the Ship Fram, 1893-96, and of a Fifteen Months' Sleigh Journey by Dr. Nansen and Lieut. Johansen. With an appendix hy Otto Sverdrup, Captain of the Fram, r2o full-page and numerous tex illustrations, 16 coloured plates in facsimile from Dr. Nansen's own sketches, etched portrait, photogravures and maps. 2 vols. Pp. I200. (Westminster Archibald Constable and Co., 1897.) 